\title{
PENGGUNAAN EXPLOSIVE LOW DENSITY PADA PELEDAKAN AREA DI BAWAH RADIUS AMAN MANUSIA DAN PENINGKATAN PRODUKTIVITY ALAT GALI DI AREA TERSEBUT PADA PENAMBANGAN BLOK B1 PIT C2 SAMBARATA MINE OPERATION PT BERAU COAL
}

\author{
Sutami Sitorus ${ }^{1}$, Elfizar Diando ${ }^{2}$ \\ sutami.sitorus@beraucoal.co.id, elfizar.diando@beraucoal.co.id
}

\begin{abstract}
ABSTRAK
Pit C2, merupakan salah satu blok penambangan Site Sambarata Mine Operation yaitu masuk ke dalam blok B1. Merupakan pit aktif hingga sekarang dimana penambangan dari 2018 hingga akhir 2019 telah mengarah ke pemukiman hingga boundary pit (2019) berjarak $200 \mathrm{~m}$ ke pemukiman terdekat dan area tersebut penambangan menggunakan peledakan.Volume overburden pada area tersebut yang termasuk zona dibawah $500 \mathrm{~m}$ jarak aman peledakan adalah $1.340 .281 \mathrm{bcm}$ dan coal sebesar 175.237 ton dengan SR 7,65. Telah diterapkan beberapa taknik peledakan pada area tersebut, yaitu salah satunya dengan sistem peledakan elektronik detonator dengan berbagai improvmentnya diantaranya : pola segementasi, segmentasi bufferzone, electronic detonator with air decking dan penggunaan matrial stemming full gravel. Kendala yang timbul adalah masalah efek peledakan yaitu vibrasi dan fly rock dengan jarak tersebut serta pembentukan bench height yang tidak maksimal karena adanya limit kedalaman lubang maksimal $5 \mathrm{~m}$ di area 500-300 $\mathrm{m}$ dari pemukiman, sehingga produktivity unit (PC 2000) tidak maksimal dan menimbulkan blasting cost yang tinggi. Penggunaan Explosives Low Density $(0,7-0,8 \mathrm{gr} / \mathrm{cc})$, di area $<500 \mathrm{~m}$ dari pemukiman bisa menambah kedalaman lubang bor hingga kedalaman $7 \mathrm{~m}$, sehingga menambah volume peledakan tanpa mengubah parameter peledakan sebelumnya yaitu : pattern peledakan, charging weight dan penggunaan sistem elektronik detonator dan juga bisa menggunakan sistem peledakan nonel. Dengan explosive low density pengingkatan column raise lubang ledak menjadi 1,3 m. Dari data digging time unit loader (PC 2000), mampu mencapai 9,9 detik dari target maksimal 11 detik, produktivity di atas $700 \mathrm{bcm} / \mathrm{jam}$ dan vibration effect yang dihasilkan masih di bawah $2,2 \mathrm{~mm} / \mathrm{sec}$ (PVS) yang menjadi patokan site. Sehingga penggunaan explosive low explosive ini bisa mempercepat sekuen penambangan di pit C2 sesuai dengan boundary disain 2019
\end{abstract}

Kata kunci : Low density, Ground vibration, fly rock, productivity

\begin{abstract}
Pit C2, is one of the Mining Samntbarata Mine Operation mining blocks, which is included in Block B1. It is an active pit up to now where mining from 2018 to the end of 2019 has led to settlements to the boundary pit (2019) within $200 \mathrm{~m}$ to the nearest settlement and the area is mining using blasting. Overburden volume in the area which includes zones below $500 \mathrm{~m}$ safe blasting distance is 1,340,281 bcm and coal of 175,237 tons with SR of 7.65. Several blasting techniques have been applied in this area, one of which is an electronic detonator blasting system with various improvements including: Segmentation pattern, buffer zone segmentation, electronic detonator with air decking and the use of full gravel matrial stemming. The obstacle that arises is the problem of blasting effects namely vibration and fly rock with that distance and the formation of bench height that is not optimal because of the maximum hole depth of $5 \mathrm{~m}$ in the area of 500$300 \mathrm{~m}$ from the settlement, so the productivity unit (PC 2000) is not optimal and causes high blasting cost. The use of Explosives Low Density $(0.7-0.8 \mathrm{gr} / \mathrm{cc})$, in the $<500 \mathrm{~m}$ area of the settlement can increase the depth of the drill hole to a depth of $7 \mathrm{~m}$, thus increasing the volume of blasting without changing the previous blasting parameters namely: blasting pattern, charging weight and the use of an electronic detonator system and can also use a nonel blasting system.
\end{abstract}


With explosive low density the column raising the explosive hole to $1.3 \mathrm{~m}$. From the digging time unit loader data (PC 2000), it can reach 9.9 seconds from the maximum target of 11 seconds, productivity above $700 \mathrm{bcm} / \mathrm{hour}$ and the resulting vibration effect is still below $2.2 \mathrm{~mm} / \mathrm{sec}$ $(P V S)$ which is the benchmark site. So that the use of low explosive explosives can accelerate the mining sequence in pit C2 in accordance with the 2019 design boundary.

Kata kunci: Low density, Ground vibration, fly rock, productivity

\section{A. PENDAHULUAN}

\section{A.1. Latar Belakang}

Penambangan Sambarata dimulai pada 2010 merupakan area operasi ke-3 PT. Berau Coal setelah Lati Mine Operation, Binungan Mine Operation. Area penambangan Sambarata atau dikenal Sambarata Mine Operation (SMO) terbagi dalam empat blok penambangan yaitu Blok A, Blok B East, Blok B West, dan Blok B1. Keadaan geologi Tambang Sambarata secara Fisiografi daerah Berau terletak pada cekungan tarakan dengan pengunungan yang umumnya rendah dengan bukit yang bergelombang. Strutur geologi yang terdapat di area Sambarata adalah struktur lipatan dan sesar. Pola Struktur lipatan dan sesar naik cenderung dominan pada arah relatif utara-selatan di bagian Utara Sambarata (Blok B) dan arah relatif Tenggara - Barat laut di bagian selatan Sambarata (Blok B1), sedangkan pola struktur sesar mendatar berada pada arah barat daya-timur laut. Terdapat dua struktur sesar mendatar, yaitu pada bagian utara Sambarata dan bagian selatan Sambarata dan pada daerah Birang (Blok B1) terdapat struktur lipatan atau Sinklin yang secara strike perlapisan menuju arah pemukiman

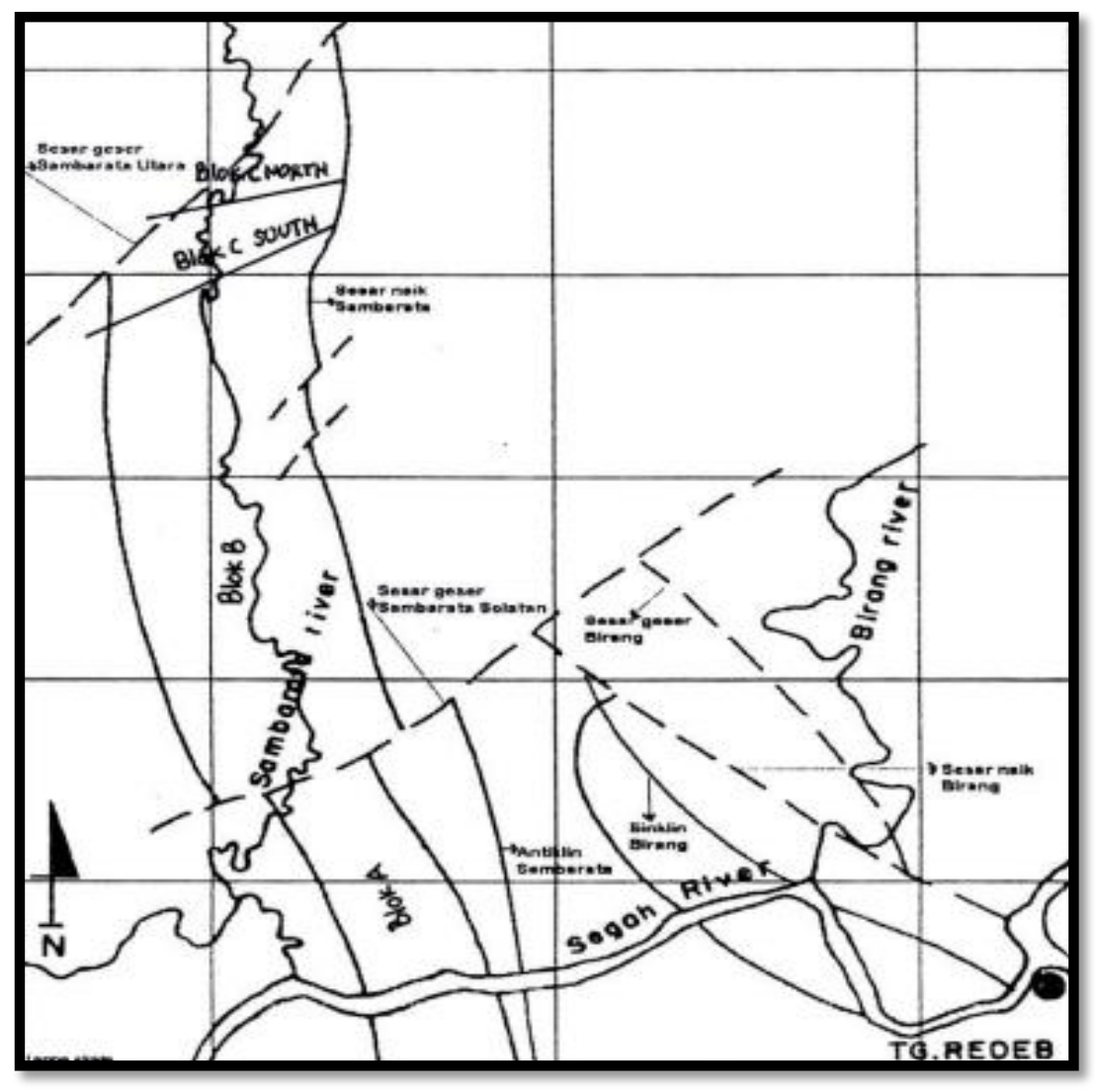

Gambar 1. Sketsa Struktur Geologi Daerah Sambarata (Berau Coal,1996). 
Rencana produksi overburden Blok B1 Pit C2 Tahun 2019 adalah sebesar 18,081,000 Bcm dan produksi batubara sebesar 1.730 .000 ton merupakan salah satu pit aktif tahun 2019 dengan boundary pit sisi selatan merupakan batasan akhir penambangan. Sisi selatan Pit C2 merupakan daerah pemukiman warga yang secara litologi permukaan atas dominan material rawa yang memiliki sifat elastis bisa menghantar efek getaran lebih besar dan terasa dari efek peledakan. Penambangan dari tahun 2018 hingga akhir 2019 telah mengarah ke pemukiman hingga boundary pit 2019 berjarak $200 \mathrm{~m}$ ke pemukiman terdekat. Kendalanya di area tersebut, penambangan menggunakan peledakan.Volume overburden pada area tersebut yang termasuk zona dibawah 500 m jarak aman peledakan adalah $1.340 .281 \mathrm{bcm}$ dan coal sebesar 175.237 ton dengan SR 7,65 yang secara ekonomis sangat menguntungkan. Di Area tersebut berdasarkan sekuen penambangan untuk mencapai target produksi ditempatkan 2 unit Loader (PC 2000).

Dengan adanya pemukiman terdekat pit $\mathrm{C} 2$ diperlukan beberapa pertimbangan dan metode agar operasional penambangan dapat berjalan dan produksi tercapai, beberapa pertimbangan untuk operasional antara lain :

1. Melakukan evakuasi warga yang masuk radius $500 \mathrm{~m}$ dari peledakan

2. Menggunakan metode Ripping

3. Metode Advance Mine Excavation

4. Metode peledakan dengan Tecnical Improvemet

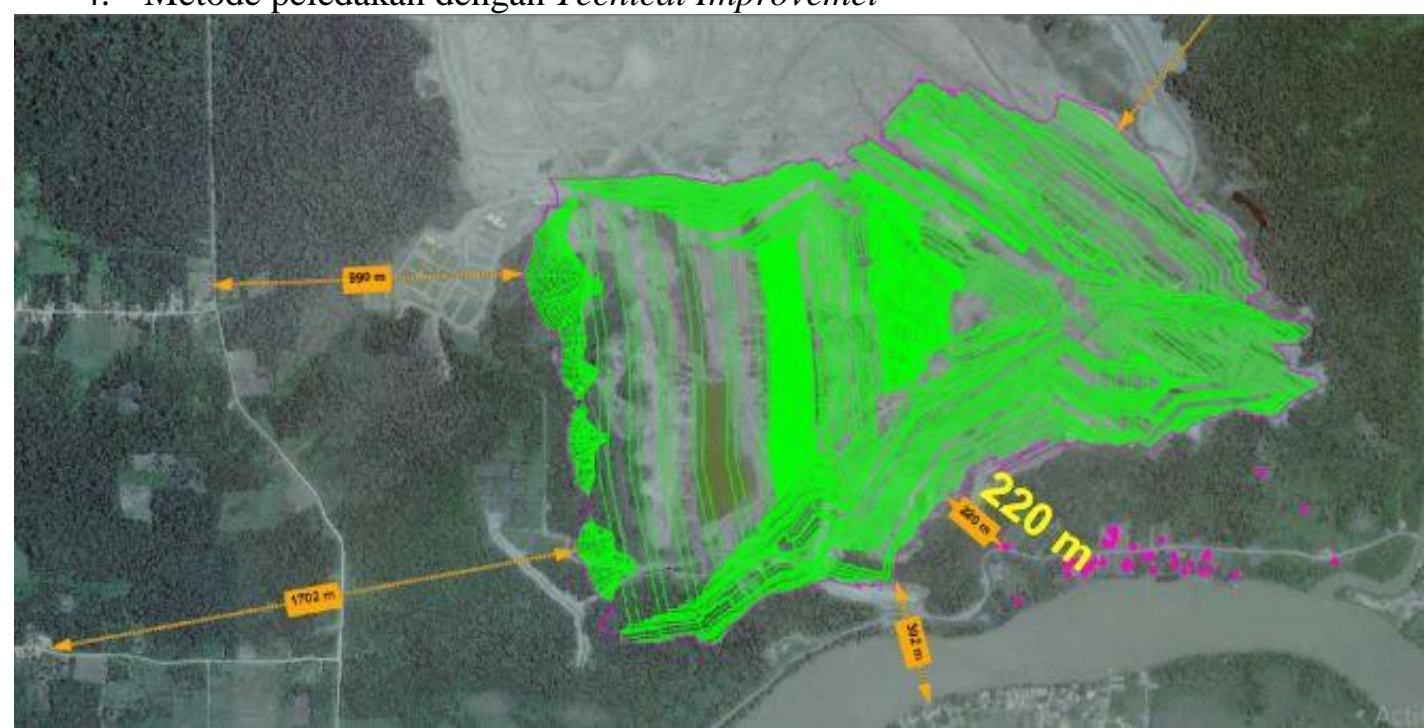

Gambar 2. Layout Pit C2 Terhadap Pemukiman.

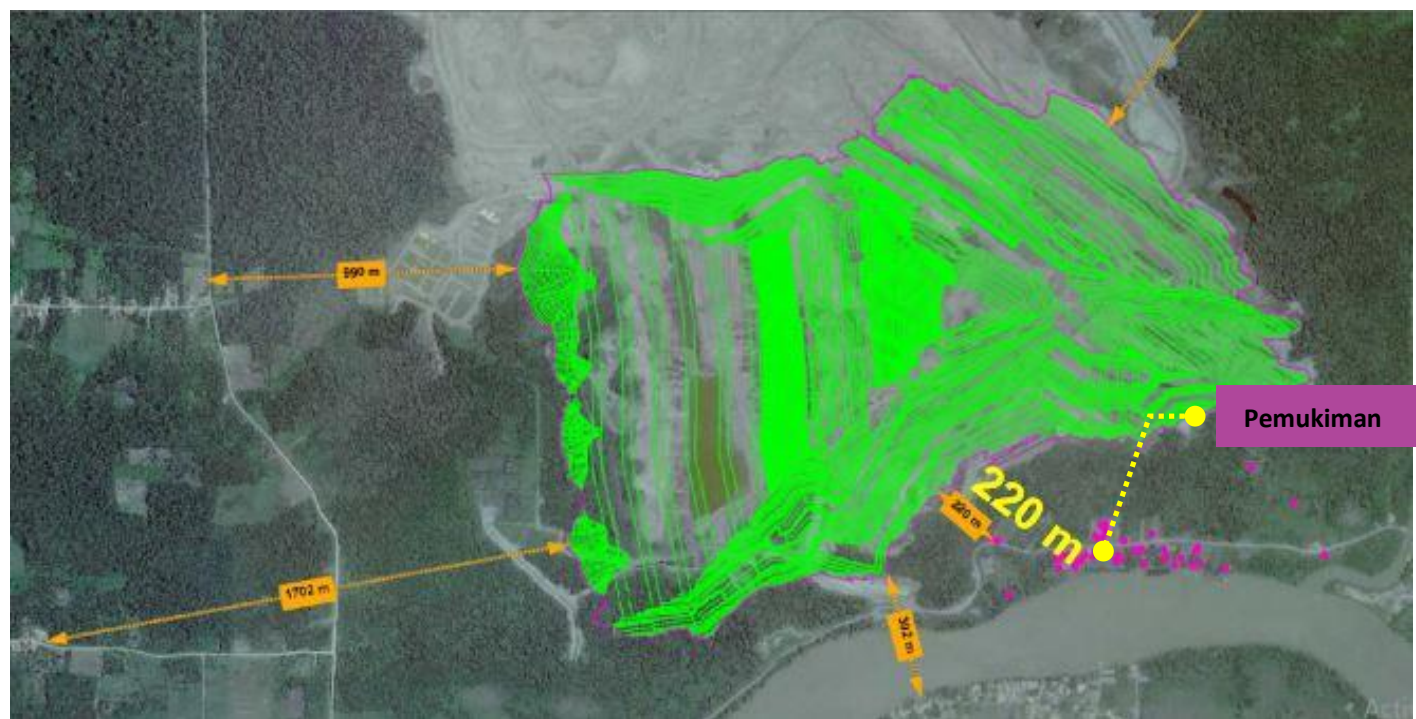

Gambar 3. Area 500 m penambangan Radius Pemukiman (arsiran dan warga magenta). 


\section{A.2. Pendekatan Pemecahan Masalah}

Jarak aman manusia terhadap radius peledakan merupakan salah satu kendala operasional rencana penambangan dikarenakan radius jarak aman manusia, jarak aman manusia sesuai dengan Standard Operasional Prosedur peledakan adalah $500 \mathrm{~m}$ namun hal ini menjadi kendala karena potensi kehilangan reserve batubara sebesar 175.237 jika tidak ditambang. Untuk itu diperlukan pemilihan metode dan cara dengan pertimbangan keamanan dan keselamatan serta pertimbangan ekonomis. Di tabel berikut menjelaskan pertimbangan yang menjadi acuan pemilihan metode :

Tabel 1. Pertimbangan pemilihan metode

\begin{tabular}{lcl}
\hline \multicolumn{1}{c}{ Metode } & $\begin{array}{c}\text { Cost Calculation } \\
(\mathbf{\$} / \mathbf{b c m})\end{array}$ & \multicolumn{1}{c}{ Potential Problem } \\
\hline Evakuasi Warga & 1,86 & Delay evakuasi, masalah sosial lain \\
Metode Ripping & 2,26 & Investasi unit, productivity alat gali \\
Advance Mine Operation & $\mathrm{n} / \mathrm{a}$ & Belum pernah teruji \\
Blasting & 0,24 & Graound vibration, fly rock \\
\hline
\end{tabular}

Melalui beberapa pembahasan dan pertimbangan baik dari teknis, efek sosial maka metode peledakan dengan advance improvment menjadi opsi yang paling baik

\section{B. KAJIAN PELEDAKAN PIT C2 SISI SELATAN}

\section{B.1. Metode Peledakan}

Telah dilakukan metode peledakan menggunakan sistem electronic detonator di area tidak aman $500 \mathrm{~m}$ manusia dari peledakan. Sistem tersebut mempunyai kelebihan : presisi delay time yang sangat baik (zero scatter time) dan pngaturan/penentuan delay time tanpa batasan sehingga tidak ada lubang ledak yang meledak bersamaan. Sehingga bisa meminimalisir efek getaran (Ground vibration). Dari pengukuran sebelumnya, penggunaan electronic detonator dapat menurunkan $30 \%$ efek getaran peledan dari sistem Non Electronic Detonator.

Dengan menggunakan Sistem peledakan Electronic juga telah dilakukan telah pengembangan yaitu kombinasi sistem peledakan elecronic dan penggunaan matrial gravel yaitu :

\section{Metode Segmentasi Electronic Detonator}

Adalah metode/rekayasa dalam rangkaian peledakan dimana lubang/zonasi yang paling dekat dengan pemukiman warga/titik kritis diledakkan terlebih dahulu yang berfungsi sebagai zona/segmentasi yang dapat mengurangi rambatan getaran di dalam perlapisan batuan. Kemudian jumlah lubang produksi dibagi lagi ke beberapa segment sesuai tahapan (grouping)

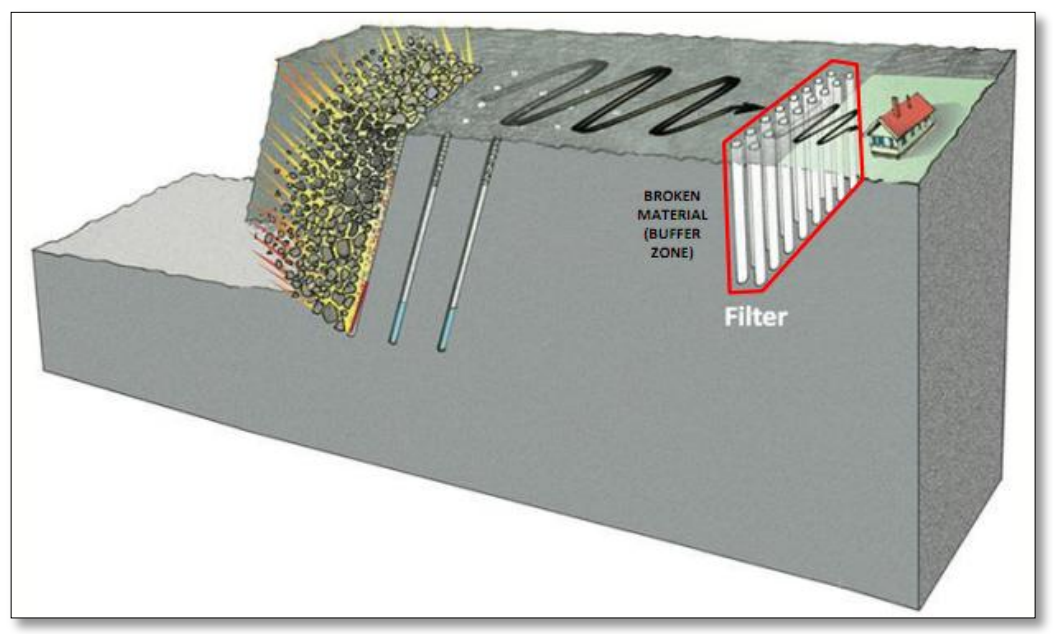


Gambar 4. Konsep segmentasi peledakan sistem electronic detonator

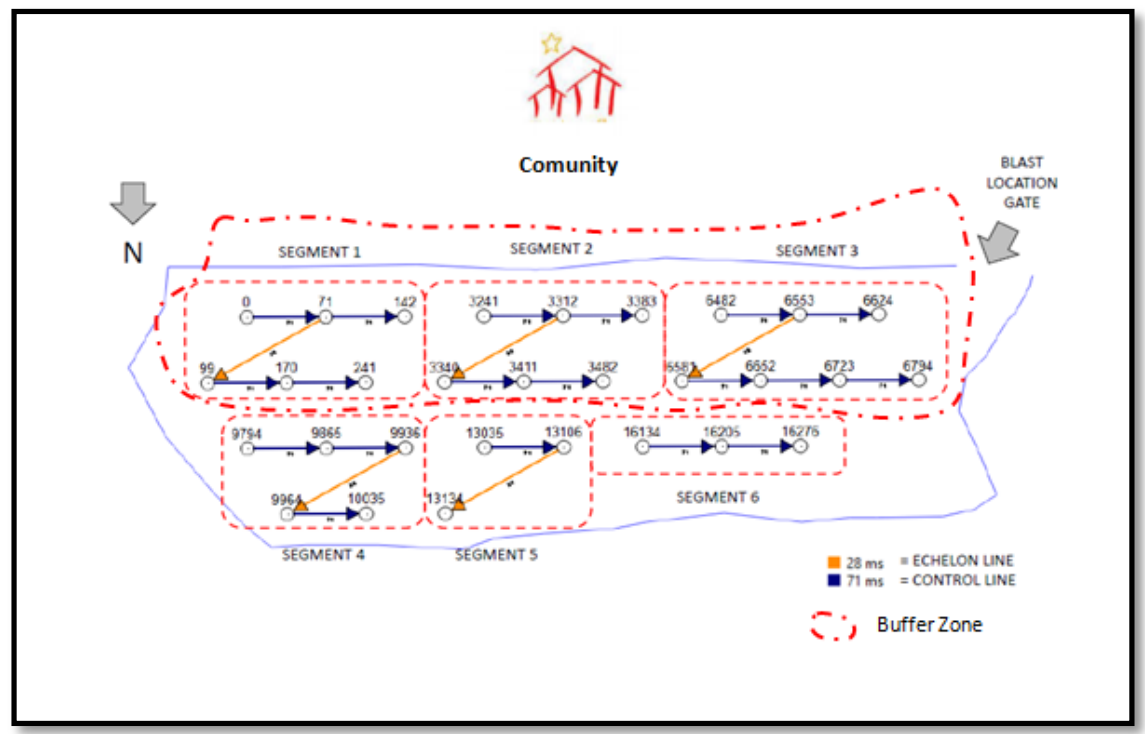

Gambar 5. Urutan Segmentasi peledakan

\section{Metode Air Deck dengan electronic detonator}

Adalah salah satu teknik dalam kegiatan peledakan yang bertujuan untuk membuat ruang hampa/deck space pada lubang ledak dengan material decking tertentu.

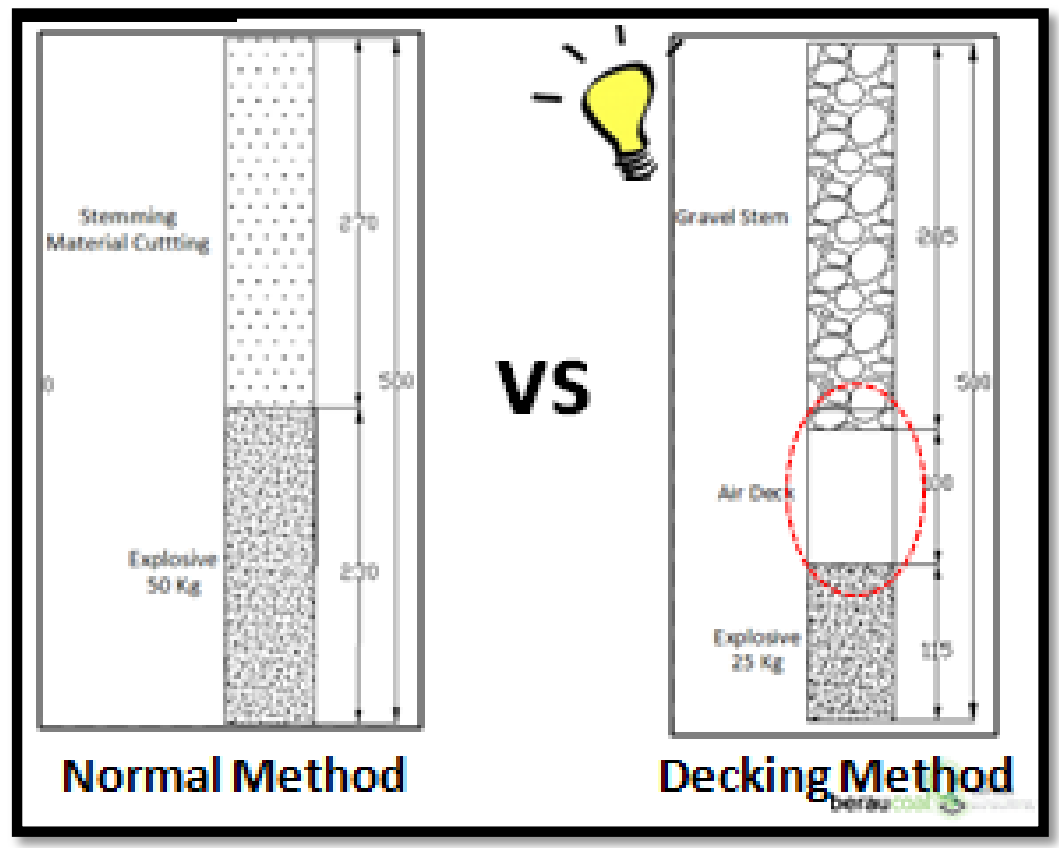

Gambar 6. Peledakan dengan Air Decking.

Metode peledakan saat ini sudah dapat diterapkan pada area tersebut dan efek dari peledakan bisa diminimalisir baik flyrock maupun ground vibrasi. Masalah yang timbul metode peledakan saat ini hanya dengan mengurangi isian bahan peledak dengan cara membatasi kedalaman lubang ledak 5 $\mathrm{m}$ di area tersebut sehingga terjadi penurunan productivity alat gali (PC 2000). Sehingga unit Loader tidak maksimal melakukan penggalian untuk spec unit tersebut sehingga productivity unit 
turun menjadi di bawah $750 \mathrm{bcm} /$ hour yang mengakibatkan produksi overburden di area tersebut menurun

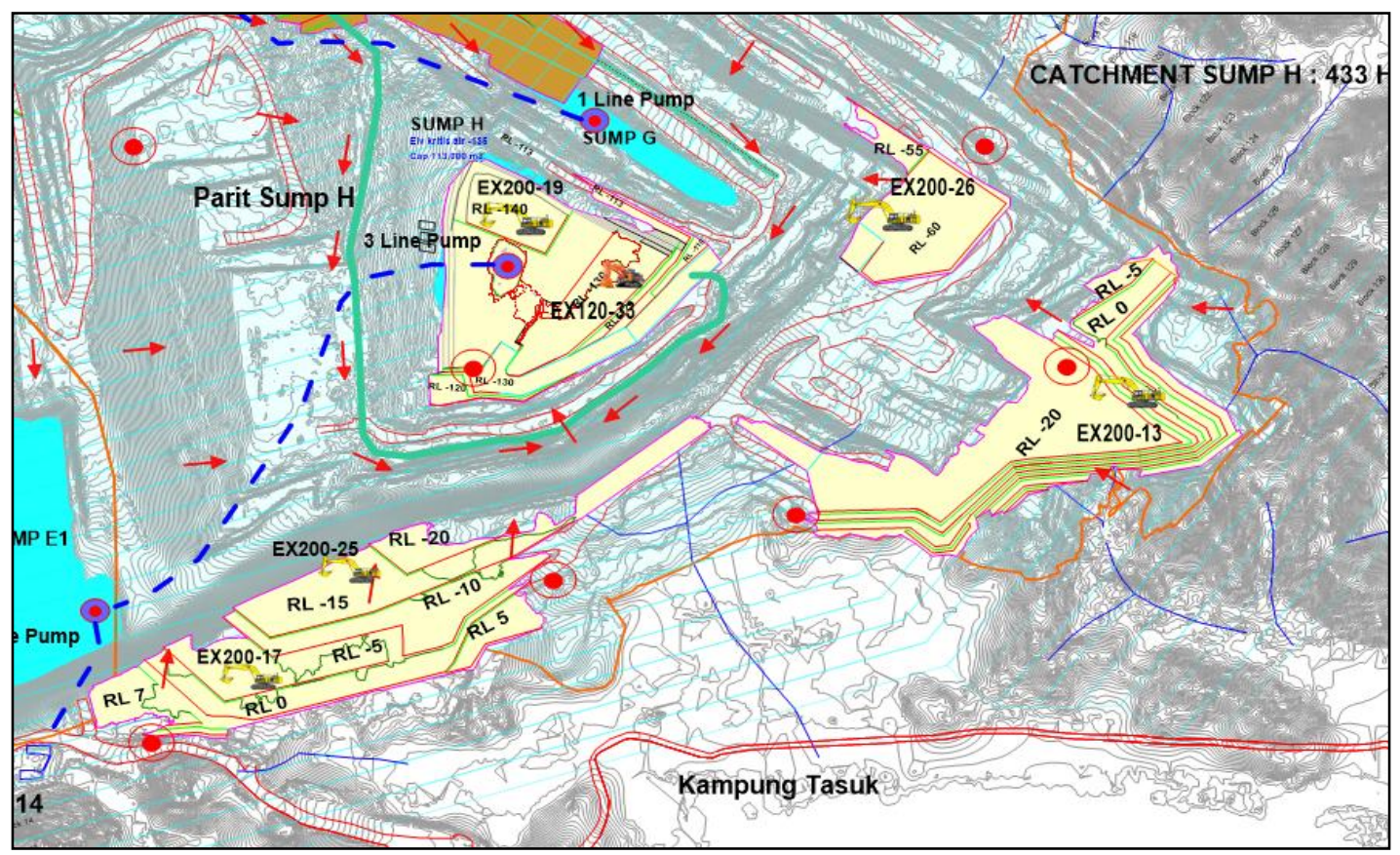

Gambar 7. Unit Loader (PC200) dan plan Productivity loader.

\section{B.2 Penggunaan Bahan Peledak Low Density}

Konsep penggunaan bahan peledak low density adalah mengurangi isian bahan peledak (charging weight) perhole tetapi sekaligus memenuhi kolom charging secara geometri melalui metode gassing tanpa merubah spesifikasi tecnical dari bahan peledak tersebut seperti Velocity of Detonation (VOD) dan energi dari bahan peledak tersebut serta tanpa merubah pattern atau geometri peledakan sehingga bisa menurunkan PF dari peledakan. Tahan terhadap air (water resistance). Dengan menurunkan densitas bahan peledak standar $(1,1 \mathrm{~g} / \mathrm{cc}) \mathrm{ke} 0,7 \mathrm{~g} / \mathrm{cc}$ dalam waktu 20 menit.

Tabel 2. Density cup dan VoD bahan peledak Low explosives

\begin{tabular}{|c|c|c|c|}
\hline$\frac{-1}{1}=\frac{12}{1}$ & $\begin{array}{l}\text { Density } \\
\left(\mathrm{g} / \mathrm{cm}^{3}\right)\end{array}$ & Average $\sqrt{\text { On }}$ & OB Productivity \\
\hline & 1,1 & 5150 & $\mathrm{Bcm} /$ Hour \\
\hline & & PC2000 & 732 \\
\hline & 1,0 & 4950 PC1250 & 403 \\
\hline & 0,9 & 4800 HD785 & 103 \\
\hline & 0,8 & 4700 HD465 & 65 \\
\hline & 0,7 & 4650 & \\
\hline
\end{tabular}

Pada kasus peledakan di Area peledakan Sambarata Pit C2, penggunaan bahan peledak Low density adalah dengan menambah kedalaman lubang ledak dari $5 \mathrm{~m}$ menjadi $7 \mathrm{~m}$ untuk memaksimalkan productivity unit loader (PC 2000) dan peningkatan volume peledakan dengan tetap 


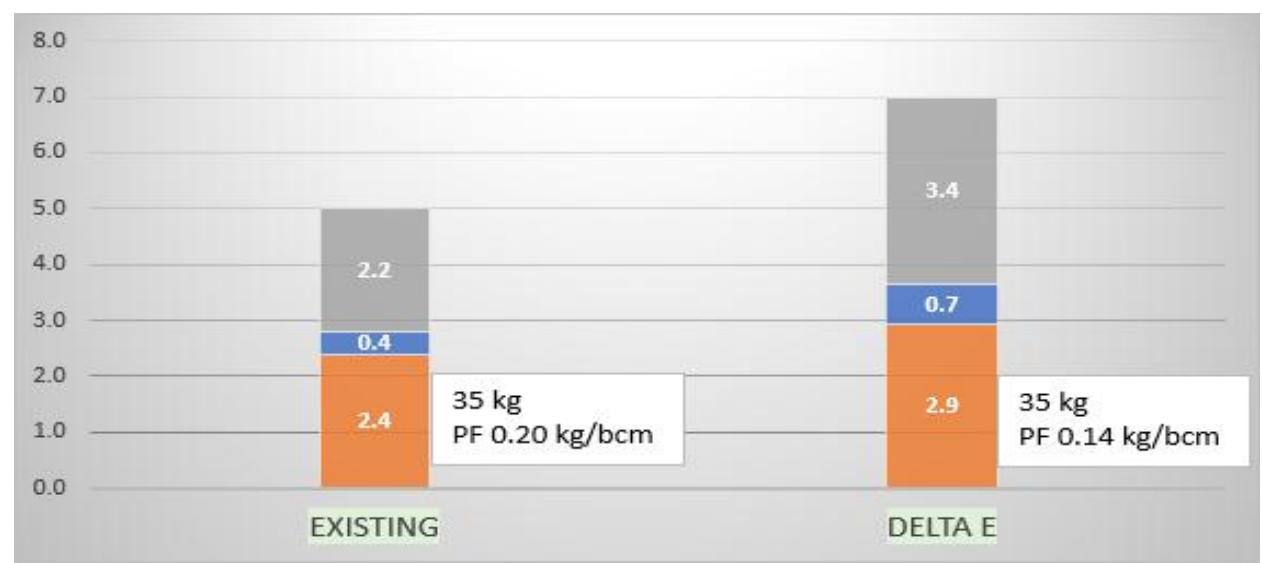

Gambar 8. Peningkatan kedalaman lubang bahan peledak Low explosives

\section{PENCAPAIAN}

Tabel berikut menjelaskan penerapan isian bahan peledak terhadap kedalaman lubang ledak di area kritis Pit C2 sebelum penggunaan bahan peledak low density

Tabel 3. Isian bahan peledak per kedalaman lubang ledak per jarak peledakan ke pemukiman

\begin{tabular}{cccccccc}
\hline \multirow{2}{*}{$\begin{array}{c}\text { Distance } \\
(\mathrm{m})\end{array}$} & \multicolumn{2}{c}{ Depth (m) } & \multicolumn{3}{c}{ Charge Weight $(\mathrm{kg})$} & \multicolumn{2}{c}{ Accessories } \\
\cline { 2 - 8 } & Depth 5 m & Depth 7 m & Max 35 kg & Max $\leq 40 \mathrm{~kg}$ & Max $\leq 70 \mathrm{~kg}$ & EDD & Nonel \\
\hline$<300$ & V & - & V & - & - & V & - \\
$300-349$ & V & - & V & - & - & V & - \\
$350-399$ & V & - & V & - & - & V & - \\
$400-449$ & V & - & - & V & - & V & - \\
$450-499$ & - & V & - & - & V & V & - \\
$500-549$ & - & V & - & - & V & - & V \\
$550-599$ & - & V & - & - & V & - & V \\
$600-649$ & - & V & - & - & V & - & V \\
$650-699$ & - & V & - & - & V & - & V \\
$>700$ & - & $7-8$ m & \multicolumn{7}{c}{ Weight charge based on depth } & - & V \\
\hline
\end{tabular}

Gambar berikut menjelaskan perubahan parameter isian bahan peledak sebelum dan sesudah pengunaan bahan peledak low density

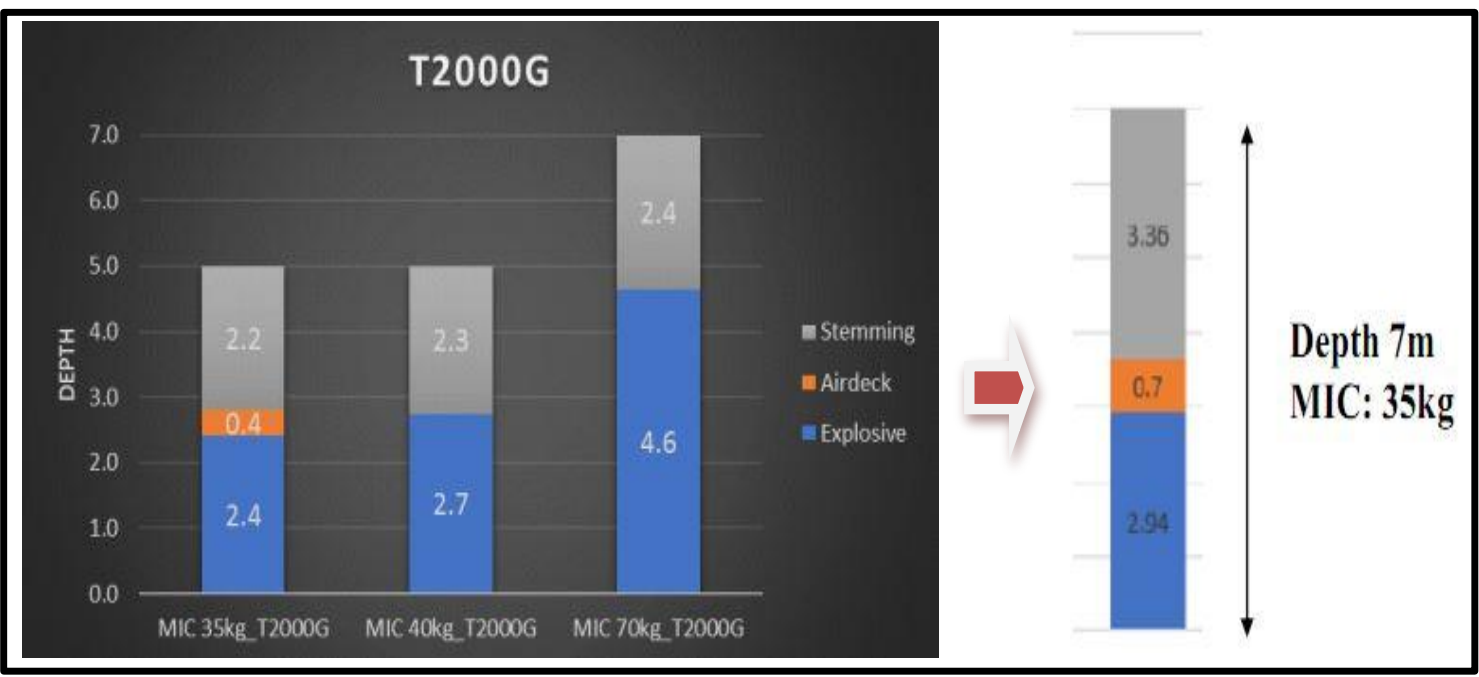

Gambar 9. Parameter isian bahan peledak standard dan bahan peledak low density 
Dari beberapa trial peledakan yang dilakukan, table summary berikut menjelaskan penerapannya pada peledakan dia area kritis Pit C2

Tabel 2. Summary peledakan

\begin{tabular}{|c|c|c|c|c|c|c|c|c|c|}
\hline \multicolumn{2}{|l|}{ Blost Number } & TRIAL 01 & TRIAL 02 & TRIAL 03 & TRIAL 04 & TRIAL 05 & TRIAL 06 & TRIAL 07 & TRIAL 08 \\
\hline \multicolumn{2}{|l|}{ Blosting Dote } & $26 / 5 / 2019$ & $26 / 5 / 2019$ & $27 / 5 / 2019$ & $28 / 5 / 2019$ & $29 / 5 / 2019$ & $29 / 5 / 2019$ & $30 / 5 / 2019$ & $4 / 6 / 2019$ \\
\hline \multicolumn{2}{|l|}{ Pit/seom } & Pitc2/Seam Kx+1 & PitC2/SeamL & Pitc2/bottom J & PitC2/BottomI & PitC2/SeamL L & PitC2/Bottom M & PitC2/Bottom I & Pitcz/Seam F timur \\
\hline \multicolumn{2}{|l|}{ Block/Elv } & Blok 79.80 Elv. $53 / .60$ & Blok $78 \cdot 79 \mathrm{Elv} \cdot 27 / 30$ & Blok 79.80 Elv.29/.30 & Blok $70-81$ Elv-55/.62 & Blok 78.79 Elv-34/.42 & Blok 79.80 Elv.37/.32 & Blok $78-79$ Elv $-30 / .37$ & Blok 77.78 Elv. $87 / .92$ \\
\hline \multicolumn{2}{|l|}{ Initiation } & Electronic & Electronic & Electronic & Nonel & Electronic & Electronic & Electronic & Nonel \\
\hline Hole Diameter & $\mathrm{mm}$ & 127 & 127 & 127 & 127 & 127 & 127 & 127 & 200 \\
\hline Total Holes & hole & 96 & 48 & 56 & 79 & 106 & 19 & 25 & 26 \\
\hline Burden & $m$ & 5.5 & 5.5 & 5.5 & 5.5 & 5.5 & 5.5 & 5.5 & 7.0 \\
\hline Spacing & $m$ & 6.5 & 6.5 & 6.5 & 6.5 & 6.5 & 6.5 & 6.5 & 9.0 \\
\hline Ave Depth & $m$ & 6.02 & 6.79 & 6.92 & 6.94 & 7.00 & 6.61 & 6.86 & 6.30 \\
\hline Averoge Steoming (Before) & $m$ & 4.20 & 4.70 & 4.90 & 4.40 & 4.90 & 4.50 & 4.50 & 4.50 \\
\hline Volume Teoritis & $B C M$ & 20652.775 & 11654.5 & 13853.125 & 19587,425 & 26526.5 & 4486,625 & 6131.125 & 10313.1 \\
\hline Totol Bulk Product & $\mathrm{Kg}$ & 2937 & 1676 & 1906 & 3271 & 3710 & 665 & 970 & 2146 \\
\hline PF teoritis & $\mathrm{kg} / \mathrm{bcm}$ & 0.14 & 0.14 & 0.14 & 0.17 & 0.14 & 0.15 & 0.16 & 0.21 \\
\hline
\end{tabular}

Dari analisa hasil peledakan diamati productivity Loader (PC 2000) di penggalian layer 1 dan layer 2 masih mencapai target perjamnya $740 \mathrm{bcm} / \mathrm{jam}$. Tabel berikut menunjukkan pencapaian productivity unit loader

Tabel 3. Productivity unit Loader (PC 2000)

\begin{tabular}{|c|c|c|c|c|c|c|c|c|c|}
\hline \multicolumn{10}{|l|}{ EXC2000 } \\
\hline \multirow{3}{*}{ Lokasi } & \multirow{3}{*}{ BLOK } & \multirow{3}{*}{ Tgl Blasting } & \multicolumn{2}{|c|}{ Tgl loading } & \multicolumn{4}{|c|}{ Pdty } & \multirow[b]{3}{*}{ Remark } \\
\hline & & & Layer 1 & Layer 2 & \multicolumn{2}{|c|}{ Layer 1} & \multicolumn{2}{|c|}{ Layer 2} & \\
\hline & & & & & Disturb (BCM/Hour) & UnDisturb (BCM/ Hour) & Disturb (BCM/ Hour) & UnDisturb (BCM/ Hour) & \\
\hline STRPL & 78.79 & 26-May-19 & $26 \cdot$ Mar -19 & $28-$ May-19 & 563.42 & 802.04 & 574.45 & 743.40 & \\
\hline EXPK+1 & 79.81 & 26-May-19 & $27 \cdot$ May 19 & & 699.60 & 824.79 & & & DEPTH VARIASI (BANYAK5 M NYA) \\
\hline BOTJ & 79.80 & $27 \cdot$ May 19 & $28 \cdot$ May $\cdot 19$ & & 583.68 & 784.05 & & & LAYER 2 DIPAKAI JALAN \\
\hline BOTI & 80.81 & 28-May-19 & $28 \cdot$ May $\cdot 19$ & $29-$ Mar -19 & 695.96 & 847.51 & 619.73 & 838.92 & \\
\hline STRPL & 78.79 & 29-May-19 & 30-Mar -19 & 31-May 19 & 610.39 & 777.21 & 659.12 & 803.59 & \\
\hline BOTJ & 78.79 & 30-May-19 & 30-May -19 & & 508.38 & & & & LAYER2 BELUM DI LOADING \\
\hline & & Average & & & 610.24 & 807.12 & 617.77 & 795.30 & \\
\hline
\end{tabular}

Dari hasil pengukuran getaran dan airblast masih mencapai sesuai nilai ambang batas di site yaitu $2,2 \mathrm{~mm} / \mathrm{s}$ kecuali pada pengukuran di lokasi seam L demana di area tersebut terdapat anomali secara geologi disebabkan kohesi batuan yang besar. Tabel beriku menununjukan pengukuran peledakan pada trial bahan peledak low density

Tabel.4 Pengukuran peledakan

\begin{tabular}{ccccccc}
\hline \multirow{2}{*}{ Date } & \multirow{2}{*}{ Area } & Block & NAB (mm.s) & MIC (kg) $\begin{array}{l}\text { Jarak } \mathbf{3 0 0 ~} \mathbf{~ m} \\
\text { Vibrasi(mm./s) }\end{array}$ & Airblast (dbA) \\
\hline 26 May & seam Kx+J & $79-80$ Elv-5/-60 & 2,2 & 35 & 1.702 & 54 \\
26 May & Seam L & $78-79 /$ Elv-27/-30 & 2,2 & 35 & 3.1 & 60 \\
27 May & Bottom J & $79-80$ Elv -29/-30 & 2,2 & 35 & 2.22 & 65 \\
28 May & Bottom I & $70-81$ Elv -55/-62 & 2,2 & 35 & 1.427 & 63 \\
29 May & Strip L & $78-79 /$ Elv-35/-42 & 2,2 & 35 & 0.553 & 59 \\
30 May & Bott J & $78-79 / E l v-30 / 37$ & 2,2 & 35 & 2.29 & 60 \\
\hline
\end{tabular}




\section{KESIMPULAN}

Dari beberapa trial yang dilakukan, penggunaan bahan peledak Low Density sangat membantu dan dalam kemajuan penambangan di area kritis yaitu area penambangan yang masuk dalam radius tidak aman manusia terhadap peledakan yaitu dibawah jarak $500 \mathrm{~m}$ dan mampu mengurangi dampak dari efek peledakan. Berikut summary benefit penggunaan bahan peledak low explosive :

1. Mengurangi penggunaan bahan peledak, yaitu dari Pf 0,18 menjadi 0,14

2. Pembentukan bench height yang ideal dan penambahan kedalaman lubak tembak dari $5 \mathrm{~m}$ menjadi $7 \mathrm{~m}$ sehingga secara disain tambang lebih rapi dan volume peledakan meningkat

3. Peningkatan productivity unit loader (PC 2000) menjadi di atas target yaitu rata-rata di atas $750 \mathrm{bcm} / \mathrm{jam}$

4. Dapat mengontrol efek peledakan ground vibrasi dan airblast yaitu tetap di bawah ambang batas di site Sambarata yaitu di bawah $2,2 \mathrm{~ms} / \mathrm{s}$ dan di bawah $70 \mathrm{dba}$

5. Diperlukan pengujian dan imporvement lanjutan dari kombinasi sistem electronic detonator segmen dan kombinasi isian bahan peledak low density

6. Perlunya kajian terhadap area per seam yang memilik anomali secara geologi untuk menentukan metode peledakan yang lebih baik

\section{DAFTAR PUSTAKA}

Engg, J. Pak, and Appl. Sci, 2015, Improving Rock Fragmentation Using Air Deck Blasting Technique, Pakistan.

Chiappetta R.F.,2004, New Blasting Technique to Eliminate Subgrade Drilling,Improve Fragmentation, Reduce Explosive Consumption \& Lower Ground Vibration

Using Low Density Explosives dari Dynonobel, diperoleh melalui situs internet:

http://www.dynonobel.com/explosive product/research and development 
PROSIDING TPT XXVIII PERHAPI 2019 